UDC 504.064: 504.3.054

DOI: $10.21668 /$ health.risk/2019.4.05.eng

\title{
ANALYSIS OF TOOLS AIMED AT MANAGUNG AMBIENT AIR QYALITY IN PERM CITY
}

\section{N.N. Zhizhin, M.S. D'yakov, M.B. Khodyashev}

The Urals State Scientific and Research Institute for Regional Ecological Issues, 61a, Komsomolsky avenue, Perm, 614039, Russian Federation

The article dwells on analyzing tools aimed at managing ambient air quality on the example of Perm city and basing on the experience in using systems for dynamic standardizing. The authors discuss advantages and drawbacks of managing ambient air quality with unified programs for calculating atmospheric contamination (Russian abbreviation UPRZA), We analyzed drawbacks in methodology that could result in overstating when emissions from stationary sources were inventoried; those drawbacks didn't allow using results of dispersion calculation for managing ambient air quality. Basing on data taken from literature sources and experience in UPRZA systems application, we suggest to cease applying UPRZA for operative ambient air quality management; instead, we propose to calculate admixtures dispersion with software that has been tested and used worldwide and that is freely accessible. Such software enables modeling actual meteorological conditions using data on wind profile and air temperature at various heights.

To manage ambient air quality due to identifying sources that cause more substantial contamination, modeling of toxicants dispersion should necessarily be based not only on data obtained from ground meteorological stations but also on data on temperatures and wind speed in the lower troposphere. To correctly calculate ground concentrations, we suggest applying the following data: results of uninterrupted control over emission sources that will be obtained via emission measuring tools according to changes made in the legislation in 2018; data on speeds of motor transport and fixation of transport flows structure recalculated into emissions from motorways; data on ground concentrations of admixtures including hydrogen sulphide and alkyl hydrosulphides that should be measured at ecological monitoring stations and measuring periodicity should not exceed 60 minutes; profiles of temperature, wind direction, and wind speed at various heights.

Key words: ambient air contamination, ambient air monitoring, monitoring posts, emissions standardizing, uninterrupted automated control, sulfur-containing compounds, ecological modeling, air probing.

Background and the current situation. taminants into the atmosphere as well as adAt present standardization of emissions is a basic mechanism for managing ambient air quality according to the RF legislation, first of all, the Federal law issued on May 04, 1999 No. 96-FZ «On ambient air protection»». To standardize emissions, juridical persons with their activities resulting in contaminants being emitted into the atmosphere accomplish inventories of such emissions and their sources in conformity with the relevant procedures fixed by the RF Government.

According to the legislation, an inventory should reveal and take into account all probable sources that can emit or discharge converse substances that can occur when technological processes are performed according to a technological regulation adopted by an enterprise. Besides, when standardizing emissions, it is necessary to take into account aggregated background contamination that occurs due to all the emission sources and is calculated basing on data collected via instrumental research at Rosgidromet monitoring posts.

According to the RF Government Regulation dated March 02, 2000 No. 183 «On standardizing emissions of adverse substances (contaminants) into the atmosphere and ad-

(C) Zhizhin N.N., D'yakov M.S., Khodyashev M.B., 2019

Nikolai N. Zhizhin - Leading engineer (e-mail: Nikolay@zhizh.in; tel.: +7 (922) 242-15-15; ORCID: https:// orcid.org/0000-0002-0876-8968);

Maksim S. Dyakov - Candidate of Technical Sciences, Deputy Director responsible for research (e-mail: dyakov@ecology.perm.ru; tel.: +7 (342) 281-85-02; ORCID: https://orcid.org/0000-0003-0750-4992);

Mikhail B. Khodyashev - Candidate of Chemical Sciences, Deputy Director responsible for technological development (e-mail: hodyashevmb@ecologyperm.ru; tel.: +7 (342)281-84-14; ORCID: https://orcid.org/0000-0003-4124-0687).

${ }^{1}$ On ambient air protection: The Federal law No. 96-FZ issued on May 04, 1999 г. (last edited on July 26, 2019). KonsultantPlus. Available at: http://www.consultant.ru/document/cons_doc_LAW_22971/(date of visit December 03, 2019). 
verse physical impacts on it» ${ }^{2}$, when standards for emissions are fixed, experts should apply relevant techniques to calculate dispersion of emitted contaminants in ambient air, including techniques applied to make aggregated calculations for cities and other settlements.

Dispersion is calculated as per data provided by inventories; to make these calculations, experts usually apply unified programs for calculating atmospheric contamination (Russian abbreviation is UPRZA). These programs allow calculating ground concentrations of contaminants. Apart from standardizing, UPRZA systems also provide a tool for selecting monitoring points and priority admixtures that are subject to obligatory control over atmospheric contamination [1-3]. And besides, results obtained via UPRZA calculations are applied in geoinformation technologies for social and hygienic monitoring of the environment and population health [4].

Practical experience gained in some Russian regions proves that it is quite efficient to apply aggregated calculations when emissions are standardized; Perm region is among them as this technique was first applied here in 1994 [5]. Experience accumulated in applying aggregated dispersion calculations in Perm region in 2000 2010 was disseminated into other regions according to the Order by the RF State Committee on the Environmental Protection No. 66 dated February 16, $1999^{3}$. «The system for dynamic analysis of the atmosphere and standardizations of contaminants emissions from industrial enterprises in Perm» («Lada» system) was created in the region. Long-term experience accumulated in applying a dynamic standardizing system that functioned in Perm region in 1994-2010 confirmed the methodology was quite efficient both for system participants (those who somehow used the environment and natural resources) and controlling authorities.

On one hand, «Lada» system gave its participants an opportunity to substantiate any changes in maximum permissible emissions
(MPE) for emission sources in case there were any changes in technological processes. On the other hand, it allowed authorities responsible for environmental protection to respond to people's complaints and unfavorable meteorological conditions thus managing ambient air quality basing on the analysis of dispersion calculation results for specific meteorological conditions; it became possible due to access to actual data on emissions from enterprises.

But at the same time, experience accumulated over years when «Lada» system functioned in Perm, apart from efficiency, also allowed revealing certain drawbacks. First of all, there were rather few monitoring posts in the state network for monitoring over ground air and it didn't allow fully taking into account background contamination thus making standardization and management less efficient. We should note that monitoring networks are not dense enough in most RF regions [6]. Secondly, monitoring posts applied for performing control over ground air contaminations are located in such points that their location doesn't allow identifying emissions from stationary sources of industrial enterprises in case winds blow in certain directions.

Locations where some posts are placed haven't been changed over the last 30 years; but cities and economic activities have been actively developing and it has resulted in such a situation when a stationary post which was previously located on an open area is now «closed» by high buildings or is located too close to sources of near-ground emissions. For example, the monitoring post No. 17 located on Svyazeva str., 52, in Industrialniy district in Perm was placed there in 80ties last century at the boundary of a housing area on leeward side from the «Osentsy» industrial facilities. At present there is a busy motorway near this post, the traffic there is intense, and there are high local concentrations of toxicants emitted by motor transport. As a result, data obtained at this post

\footnotetext{
${ }^{2}$ On standardizing emissions of adverse substances (contaminants) into the atmosphere and adverse physical impacts on it: The RF Government Regulation No. 183 dated March 02, 2000 г. (edited on April 22, 2009 г.). Available at: https://prirodnadzor.admhmao.ru/dokumenty/rf/228670/ (date of visit December 03, 2019).

${ }^{3}$ On applying a system of aggregated calculations when standardizing emissions: the Order by the RF State Committee on the Environmental Protection No. 66 dated February 16, 1999. Available at: http://docs.cntd.ru/document/901729767 (date of visit December 03, 2019).
} 
can't be applied for monitoring over influences exerted by the «Osentsy» industrial facilities on air contamination in the city.

Thirdly, OND-86 procedure applied within «Lada» system which is a component in «Ecologist - city» UPRZA software package is aimed at standardizing emissions into the atmosphere. Calculation is performed either for a set of meteorological parameters or for a single wind speed and direction. Such a procedure for calculating doesn't allow using historical data on changes in wind directions, data on a wind direction and speed at a specific height (wind profile) and temperature profile of the atmosphere. Still, at present there is an opportunity to measure a wind profile and temperature profile of the atmosphere in a city [7].

As «Lada» system didn't provide an opportunity to use complete initial data, calculated contributions made by contamination sources into actual concentrations measured at monitoring posts were determined only roughly; calculated concentrations didn't correspond to those actually measured at monitoring posts. Data obtained via such calculations didn't allow unambiguous identifying sources of elevated air contamination and, consequently, didn't allow creating relevant management activities.

The system for dynamic standardization stopped its functioning in Perm in 2007 and providing even partial management over ambient air quality became impossible. At present air contamination is only measured by the Perm Center for Hydrometeorology and Environmental Monitoring (hereinafter called CHEM).

As per data provided by the Perm CHEM, there are seven posts for ground air monitoring now functioning in Perm [8]; their locations are shown in Figure 1. Table 1 contains a list of admixtures controlled at these posts; a post number corresponds to its number given in Figure 1.

According to accreditations granted to the Perm CHEM «ROSS RU.0001.512591» ${ }^{4}$, contaminants are analyzed with conventional techniques within ranges given in Table 2 . Techniques applied for measuring concentrations of all substances, excluding carbon

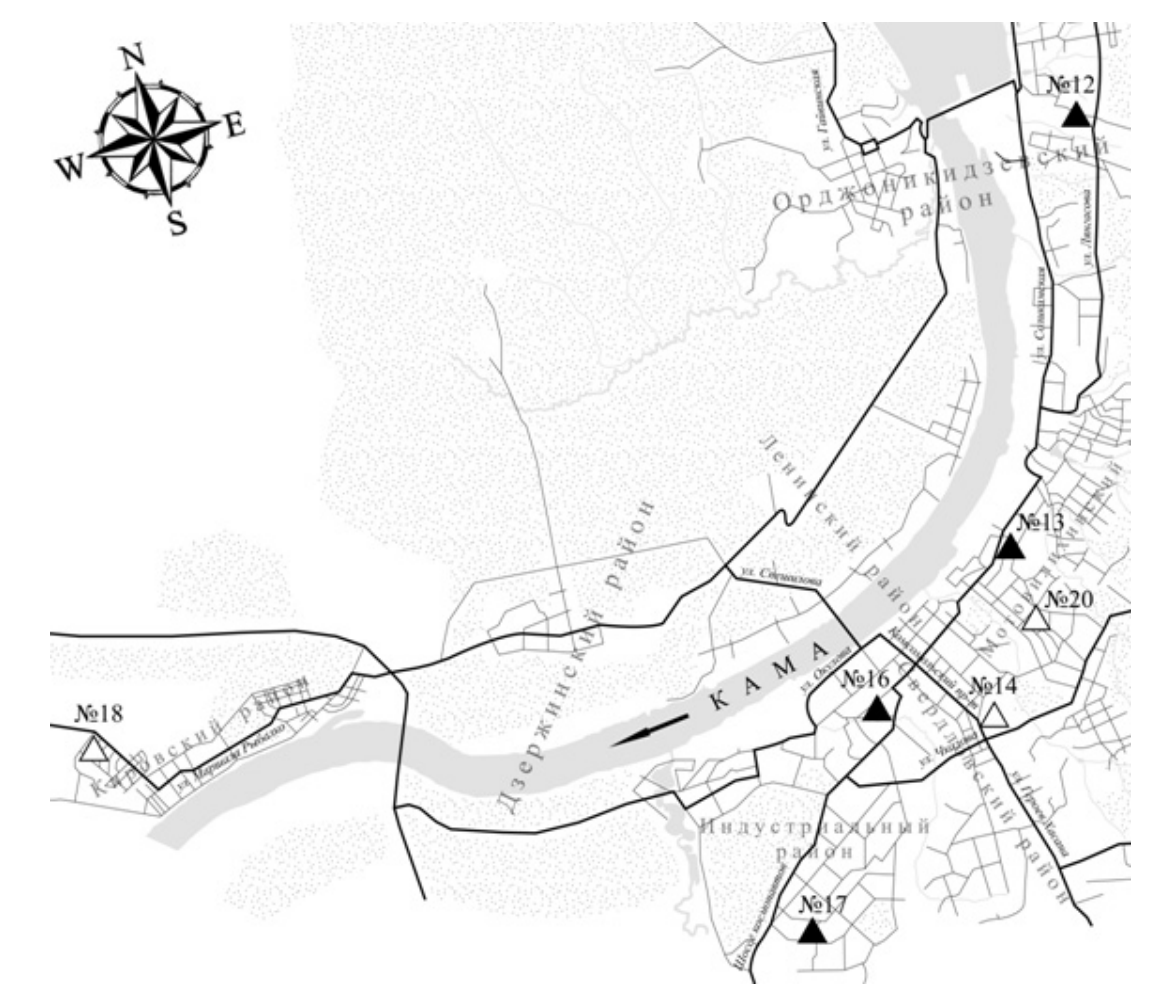

Figure 1. Location of monitoring posts aimed at controlling ambient air pollution in Perm

\footnotetext{
${ }^{4}$ Competency certification PKZ-100 issued on November 08, 2019. The Federal Accreditation Service official web-site. Available at: https://pub.fsa.gov.ru/ral/view/6754/current-aa (date of visit December 05, 2019).
} 
A list of admixtures controlled at monitoring posts in Perm

Table 1

\begin{tabular}{|l|c|c|c|c|c|c|c|}
\hline \multirow{2}{*}{ Admixtures that are subject to control } & \multicolumn{7}{|c|}{ A post No., analysis performance } \\
\cline { 2 - 9 } & 12 & 13 & 14 & 16 & 17 & 18 & 20 \\
\hline Sulfuric anhydride & $\mathrm{X}$ & & & $\mathrm{X}$ & $\mathrm{X}$ & & $\mathrm{X}$ \\
\hline Nitrogen dioxide & $\mathrm{X}$ & $\mathrm{X}$ & $\mathrm{X}$ & $\mathrm{X}$ & $\mathrm{X}$ & $\mathrm{X}$ & $\mathrm{X}$ \\
\hline Carbon oxide & $\mathrm{X}$ & $\mathrm{X}$ & $\mathrm{X}$ & $\mathrm{X}$ & $\mathrm{X}$ & & $\mathrm{X}$ \\
\hline Ammonia & $\mathrm{X}$ & $\mathrm{X}$ & $\mathrm{X}$ & $\mathrm{X}$ & $\mathrm{X}$ & $\mathrm{X}$ & \\
\hline Formaldehyde & $\mathrm{X}$ & $\mathrm{X}$ & $\mathrm{X}$ & $\mathrm{X}$ & $\mathrm{X}$ & $\mathrm{X}$ & \\
\hline Xylol & $\mathrm{X}$ & $\mathrm{X}$ & $\mathrm{X}$ & $\mathrm{X}$ & $\mathrm{X}$ & $\mathrm{X}$ & \\
\hline Toluene & & $\mathrm{X}$ & $\mathrm{X}$ & $\mathrm{X}$ & $\mathrm{X}$ & $\mathrm{X}$ & \\
\hline Benzene & & $\mathrm{X}$ & $\mathrm{X}$ & $\mathrm{X}$ & $\mathrm{X}$ & $\mathrm{X}$ & \\
\hline Ethyl benzene & $\mathrm{X}$ & $\mathrm{X}$ & $\mathrm{X}$ & $\mathrm{X}$ & $\mathrm{X}$ & $\mathrm{X}$ & \\
\hline Phenol & $\mathrm{X}$ & & $\mathrm{X}$ & $\mathrm{X}$ & $\mathrm{X}$ & $\mathrm{X}$ & $\mathrm{X}$ \\
\hline Hydrogen sulphide & & & & & $\mathrm{X}$ & $\mathrm{X}$ & \\
\hline $\begin{array}{l}\text { Metals (Manganese, Copper, Nickel, Lead, } \\
\text { Chromium, Zink, Cadmium, Iron) }\end{array}$ & & & $\mathrm{X}$ & & $\mathrm{X}$ & & \\
\hline Hydrogen chloride & $\mathrm{X}$ & & $\mathrm{X}$ & $\mathrm{X}$ & & $\mathrm{X}$ & $\mathrm{X}$ \\
\hline Chlorine & & & & & & $\mathrm{X}$ & \\
\hline Hydrogen fluoride & $\mathrm{X}$ & & $\mathrm{X}$ & & & $\mathrm{X}$ & \\
\hline Particulate matter & $\mathrm{X}$ & $\mathrm{X}$ & & $\mathrm{X}$ & & $\mathrm{X}$ & \\
\hline Nitrogen oxide & & & $\mathrm{X}$ & $\mathrm{X}$ & & & \\
\hline
\end{tabular}

List of contaminants, techniques and detection ranges

Table 2 (according to accreditation granted to the Perm CHEM)

\begin{tabular}{|c|c|c|}
\hline Detected contaminants & $\begin{array}{c}\text { Documents that fix rules and techniques for research } \\
\text { and measuring }\end{array}$ & $\begin{array}{l}\text { Detection range, } \\
\mathrm{mg} / \mathrm{m}^{3}\end{array}$ \\
\hline Sulfuric anhydride & RD 52.04.822-2015 & $0.0025-8.0$ \\
\hline Nitrogen dioxide & RD 52.04.792-2014 & $0.021-4.3$ \\
\hline Carbon oxide & «Elan» gas analyzer User manual EKIT 5.940.000RE & $0.6-50.0$ \\
\hline Ammonia & RD 52.04.791-2014 & $0.02-5.0$ \\
\hline Formaldehyde & RD 52.04.824-2015 & $0.01-0.3$ \\
\hline Xylol & \multirow{4}{*}{ RD 52.04.838-2015 } & $0.02-5.0$ \\
\hline Toluene & & $0.02-5.0$ \\
\hline Benzene & & $0.02-5.0$ \\
\hline Ethyl benzene & & $0.01-5.0$ \\
\hline Phenol & RD 52.04.799-2014 & $0.003-0.1$ \\
\hline Hydrogen chloride & RD 52.04.795-2014 & $0.006-0.1$ \\
\hline Hydrogen chloride & RD 52.04.793-2014 & $0.04-2.0$ \\
\hline Chlorine & «Elan» gas analyzer User manual EKIT 5.940.000RE & $1.0-10.0$ \\
\hline Hydrogen fluoride & RD 52.04.797-2014 & $0.002-0.2$ \\
\hline Particulate matter & RD 52.04.186-89 part $1 \mathrm{sec} .5 .2 .6$ & $0.26-50.0$ \\
\hline Nitrogen oxide & RD 52.04.792-2014 & $0.028-2.8$ \\
\hline Chromium & \multirow{8}{*}{ RD 52.04.186-89 part 1 sec. 5.2.5.2 } & $0.01-1.5$ \\
\hline Lead & & $0.06-1.5$ \\
\hline Manganese & & $0.01-1.5$ \\
\hline Nickel & & $0.01-1.5$ \\
\hline Zink & & $0.01-1.5$ \\
\hline Copper & & $0.01-1.5$ \\
\hline Iron & & $0.01-1.5$ \\
\hline Cadmium & & $0.002-0.24$ \\
\hline
\end{tabular}


monoxide and chlorine monoxide, involve laboratory analysis of samples taken on absorbers. Therefore, the existing monitoring system doesn't allow uninterrupted obtaining of data on ground air contamination.

As dynamic standardization of emissions into the atmosphere is no longer performed, actual data on emissions from enterprises are also not collected in real time mode; data that are submitted every 5 years to substantiate standards for MPE can't be applied for modeling actual ambient air contamination. It partly explains substantial differences between calculated and actual data. Let us illustrate this situation with an example of an oil-processing plant located in Perm.

Data obtained via inventories performed at the said oil-processing plant revealed that emissions from contamination sources that were determined mostly with instrumental techniques changed considerably even when there were no changes in technological processes and the plant operated in its normal regime. This changeability is due to oil-processing being flexible as it allows satisfying changing market demands for a wide range of oil products with minimal costs taking into account changes in raw materials structure. For example, $\mathrm{SO}_{2}$, and $\mathrm{NO}_{\mathrm{x}}$ emissions from smoke pipes of technological furnaces can vary considerably as there are wide ranges for regulated changes in the structure of fuel that is manufactured by the plant, consumption of flows that are heated in these furnaces, and their structure. There are several factors that explain it, for example, a change in a share of liquid fuel that is used when gas fuel doesn't have sufficient heatproducing capacity; a change in production processes loading resulting in intermediate flows changing their direction and this, in its turn, leads to a change in the structure of gas fuel used in technological furnaces; a change in consumption of flows that are heated in furnaces and in their structure.

Emissions can be changeable not only in oil-processing but also at any other large industrial production. However, the existing standardization system doesn't allow taking into account possible changes in emissions and it makes its participants (economic entities or industries) fix higher standards for emissions than it is required in order to minimize risks of violating MPE.

Trying to take into account emissions changeability that can occur in future, economic entities develop their standards with MPE fixed at their maximum possible level for the maximum number of emission sources. Therefore, any report on an inventory basically contains only data on maximum emissions out of large data arrays obtained via measuring. As a result, even when maximum permissible level is reached at not more than 10 per cent of all the emission sources, dispersion calculation is based on modeling a situation when maximum number of emissions sources (ideally, all of them) emit maximum possible quantities of contaminants. Obviously, such a situation is impossible in real life.

The situation with fixing higher standards for emissions which is described above, apart from emission changeability, is due to the following drawbacks related to standardizing:

- firstly, as standards are fixed for a future period of time but on the basis of emissions measuring performed in the past, than, obviously, when instrumental control techniques are applied, it is necessary to predict that previously fixed operating conditions will be repeated; the task seems labor-consuming and sometimes even impossible;

- secondly, even if emissions are relevantly predicted, it is next to impossible to take into account all permissible emissions when calculating their dispersion as a number of emissions combinations that are to be modeled given a great number of emissions sources goes to infinity. Let us illustrate the last postulate with the following example.

Let us assume that there are two technological furnaces at an enterprise; they can emit nitrogen oxide $\left(\mathrm{NO}_{\mathrm{X}}\right)$ in a quantity up to $5 \mathrm{~g} / \mathrm{sec}$. Changes in emissions are caused by changes in fuel consumption that occurs due to changes in heated hydrocarbons flows. Probable combinations of emissions from the furnaces correspond to points located within the square area limited with the coordinate grid given in Figure 2 with its sizes being $5 \times 5 \mathrm{~g} / \mathrm{sec}$. Let us assume that an enterprise is located in an area where high background $\mathrm{NO}_{\mathrm{X}}$ concentrations don't allow providing air quality that conforms to sanitary stan- 
dards at the boundaries of a sanitary protection zone and beyond it when both furnaces emit their maximum quantity of $5 \mathrm{~g} / \mathrm{sec}$.

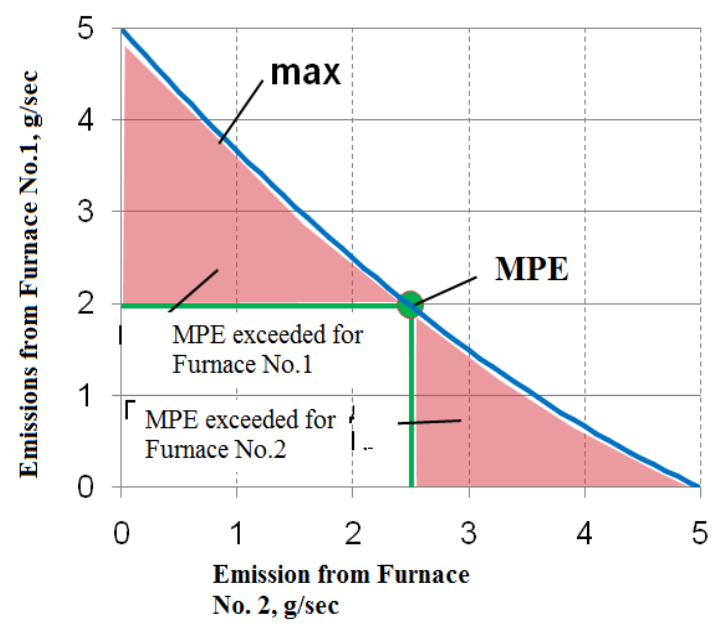

Figure 2. Illustration for combined emissions from two sources

In this case, to fix MPE standards for this enterprise, we should limit a possible emissions area with a certain line and coordinates axes. Hereinafter in this paper we call it «a permissible area». Boundaries of «a permissible area» for two emissions sources can be limited with a line given in Figure 2 as «max». Boundaries of this «permissible area» are determined with some UPRZA dispersion calculations performed with a conventional technique ${ }^{5}$.

The existing standardization system fixes that there is the only possible choice of emissions combination given in Figure 2 and it is «MPE» point with its coordinated being $2.5 \mathrm{~g} / \mathrm{sec}, 2 \mathrm{~g} / \mathrm{sec}$. And here a set of points that are located in areas limited in Figure 2 with coordinates $2.5 \mathrm{~g} / \mathrm{sec}, 2 \mathrm{~g} / \mathrm{sec}$ and «max» line corresponds to actually permissible emissions that are considered to be violations if the existing standardization system is applied.

If we apply the same logic to three emission sources, we will obtain a permissible area and a point that corresponds to MPE within a threedimension coordinates system. In real life, an oil-processing plant can have more than a dozen smoke pipes only, and similar assumptions will lead to n-dimension image of permissible emissions combinations and MPE standards.

As a result, despite there is a theoretical possibility to develop MPE with a great number of emission combinations, experts usually prefer to fix greatest possible MPE but confine themselves to only one dispersion calculation variant. Therefore, authentic data obtained via inventories of certain air contamination sources that are applied for substantiating standards don't allow estimating actual emissions from an enterprise and perform relevant calculations of ground concentrations thus detecting sources that cause elevated ambient air contamination. Ultimately, it doesn't allow environmental authorities to take well-grounded decisions related to managing ambient air quality.

Sanitary standards for ambient air quality are to be met; provision of that remains one of the most significant tasks all over the world, including Russia [9]. As per WHO data, more than $92 \%$ people in the world live on territories where ambient air contamination exceeds official safety standards [10]; therefore, tools for monitoring and managing ambient air quality are to be constantly developed and the task will become even more vital in the future [11-13].

Suggested tools for monitoring and management. Given all the above mentioned drawbacks that the existing standardization and monitoring system has, it seems advisable to perform the following tasks in order to provide proper functioning of a system for managing ambient air quality in any industrial center:

1. To provide a monitoring system with the most detailed and operative data on emissions from industrial enterprises and motor transport;

2. To provide a monitoring system with data that are uninterruptedly obtained from stationary monitoring posts; these are data on ground concentrations of contaminants emitted from enterprises located in a region including substances with a foul smell such as hydrogen sulphide, thiols, etc.;

3. To provide a monitoring system with actual data on temperatures as well as wind speeds and directions at a height up to 1,000 meters;

\footnotetext{
${ }^{5}$ On approving techniques for calculating dispersion of adverse substances (contaminants) emitted into the atmosphere: The Order by the RF Ministry for Natural Resources and Ecology No. 273 issued on June 06, 2017. Garant: information and legal portal. Available at: https://www.garant.ru/products/ipo/prime/doc/71642906/ (date of visit December 03, 2019).
} 
4. To apply mathematical tools and procedures that have already been tested in the world practice and applied for modeling dispersion of contaminants. And here we should remember that calculation techniques applied for standardizing including aggregated dispersion calculations can't be used in operative monitoring as they are aimed at calculating maximum concentrations under the worst possible combinations of meteorological parameters and they don't allow taking into account winds with changing speeds and directions occurring in various layers of the atmosphere.

The first task can be solved due to emission sources being equipped devices for with uninterrupted control; these devices are to be applied at objects that belong to the first hazard category (in other words, they can cause the most adverse effects) in conformity with amendments made into the RF legislation in $2018^{6}$.

We should note that there should be data on emissions of $\mathrm{SO}_{2}, \mathrm{NO}_{\mathrm{X}}$, and $\mathrm{CO}$ from smoke pipes in a monitoring system as these contaminants make the greatest contribution into aggregated emissions; probably, it will allow applying emissions of these contaminants as indicators for adjusting models for contaminants dispersion. Any conclusion on whether data coming from uninterruptedly controlled sources are sufficient can be made only after tasks $2-4$ are also fulfilled.

An oil-processing plant was assessed regarding how well it was equipped with meters described in the RF Government Orders dated
March 13, 2019 No. 262 and 428-r ${ }^{7}$; the assessment revealed that uninterrupted control devices should be placed on smoking pipes of technological furnaces as they account for $80 \%$ of such contaminants as $\mathrm{SO}_{2}, \mathrm{NO}_{\mathrm{X}}$, and $\mathrm{CO}$ emitted into the atmosphere. However, according to a preliminary assessment, such meters will uninterruptedly control not more than $46 \%$ of the aggregated emissions from a given enterprise. Therefore, even when the above-mentioned RF Government Orders are met, data on emissions that account for $53 \%$ of the overall atmospheric contamination will not be included into uninterrupted monitoring. Monitoring won't either cover sources that emit substances with foul smell (hydrogen sulphide, thiols, etc.) and it is these substances people mostly complain about.

A lot of authors note that recently motor transport has been making the greatest contribution into ambient air contamination in cities [14] so it can't be neglected within a monitoring system. To take emissions from motor transport into account, experts can apply a procedure for uninterrupted monitoring of emissions based on uninterrupted measuring of transport flows in a city; the procedure was tested in Saint Petersburg. To measure transport flows, experts applied data on speed of movement shown in internet resources such as «Yandex. Traffic Jams» ${ }^{9}$. An these data on how fast transport flows move can be bound to data on quantity and types of transport obtained as per data collected with video-registration devices with image recognition ${ }^{10}[15]$.

\footnotetext{
${ }^{6}$ On making alterations into the Federal law "On environmental protection" into Clauses 1 and 5 of the Federal law "On making alterations into the Federal law "On environmental protection" and certain legislative acts of the Russian Federation" as regards creating systems for automated control over emissions and discharges of contaminants: the federal law issued on July 29 , 2018 No. 252-FZ (the last edition). KonsultantPlus. Available at: http://www.consultant.ru/document/cons_doc_LAW_303483/ (Date of visit December 04, 2019).

${ }^{7}$ Technical devices, equipment or their combinations that should be places at objects belonging to the $1^{\text {st }}$ hazard category, stationary sources of contaminants emissions and discharges that are to be equipped with automated devices for measuring contaminants emissions or discharges as well as with technical means for fixing and transferring data on contaminants emissions and discharges into the state register of objects that exert negative influence on the environment: The RF Government Order No. 428-r dated March 13, 2019. Available at: https://rulaws.ru/goverment/Rasporyazhenie-Pravitelstva-RF-ot-13.03.2019-N428-r/ (date of visit December 04, 2019).

${ }^{8}$ The procedure for detecting emissions of adverse substances (contaminants) from transport flows on motor ways in Saint Petersburg into ambient air / confirmed by the Order by the Committee on use of natural resources, environmental protection and ecological safety provision in Saint Petersburg No. 23-r dated February 17, 2012. SPb, 2012, 46 p.

${ }^{9}$ Yandex.Traffic jams. Wikipedia. Free encyclopedia. Available at: https://ru.wikipedia.org/wiki/Yandex.Trafficjams (date of visit December 05, 2019).

${ }^{10}$ Kuz'min D.M. Technologies and procedures for intellectual monitoring over transport flows and motorways conditions: abstract of the thesis. ... Candidate of Technical Sciences. Moscow, 2008, 191 p.
} 
To solve the task II, we need data on ground concentrations of contaminants emitted from enterprises and motor transport that are measured on monitoring posts either uninterruptedly or with a periodicity nor exceeding 60 minutes. As at the moment there are no technical devices for uninterrupted control over ground air, we suggest starting with data obtained from additional posts for uninterrupted automated control placed by large industrial enterprises in zones influenced by their activities. All the monitoring posts within Rosgidromet system where sampling is performed only periodically should be obligatorily equipped with devices for uninterrupted control and data transfer; it is also necessary to place additional posts with uninterrupted measuring and data transferring into a unified information and analytical center.

To control ground concentrations of substances with a foul smell, in our opinion, it is necessary to equip all the posts with devices for uninterrupted measuring of total concentrations of sulfur-containing substances, hydrogen sulphide, thiols, and sulfur dioxide.

Bearing in mind, that locations where some monitoring posts are placed no longer conform to requirements fixed in RD 52.04.186-89 ${ }^{11}$ due to changes in a city environment, it is necessary to move CHEM monitoring posts to places determined as per calculations of contaminants dispersion taking into account location of motor ways and houses.

Experts in Perm accumulated certain experience in placing additional posts for control over ambient air quality within a zone influenced by an oil-processing plant. This experience revealed that there was an obstacle in selecting the most optimal location for placing a monitoring post; namely, it was impossible to get an agreement from Rosreestr authorities to make amendments into a list of activities that could be performed on a land spot in order to locate a monitoring post (a pavilion, fence, or a device for remote protection and data transfer) on it. To avoid the problem in future, there should be amendments made into the legislation; these amendments are to allow making priority changes into permitted activities on land spots thus granting permission to acquire or rent land spots for placing monitoring posts on them.

To complete Task III, we should start with data on temperature profiles applied for monitoring over contaminants spread. Taking into account analysis of temperature profiles it is possible to obtain a relevant model for contaminants transfer; it seems to be incorrect to neglect data on temperature profile of the lower troposphere.

In our opinion, we should also use data of wind aerostatic sounding obtained twice a day together with data on temperature profiles. However, according to modeling results [16] confirmed with results of temperature-wind atmosphere sounding [17], zones with elevated changeability in wind direction can occur over urban and industrial territories; therefore, existing periodicity applied for obtaining data on wind profiles is insufficient for operating management of ambient air quality. Nevertheless, data obtained via aerostatic sounding can be applied at a primary stage in adjusting dispersion models.

There are tools for uninterrupted remote wind sounding of the atmosphere applied in the world; they are so called wind profilers. The most widely used technology here is application of acoustic or radar phase-locked antenna arrays in ultrasound sodars or radars operating within a range from $1 \mathrm{~mm}$ to $30 \mathrm{~cm}$. There are also lidars or profilers that measure Doppler shift in laser radiation frequency to obtain data on a wind and temperature profile as per atmospheric height [18].

A cost-saving choice on equipment can be «XFAS» sodar with phase-locked antenna array produced by Scintec AG (Germany) (according to the manufacturer's data, it costs approximately 100 thousand EUR).

To fulfill Task IV, we suggest using freely available software packages that are described in detail on the web-site of the Support Center for Regulatory Atmospheric Modeling (SCRAM) that belongs to the US Environmental Protection Agency [19].

These packages apply a combination of the following calculation techniques:

- Receptor Modeling including PMF or Positive matrix factorization that are based on

${ }^{11}$ RD 52.04.186-89. Guide on control over ambient air contamination (Part I. Sections 1-5). Available at: http:// docs.cntd.ru/document/1200036406 (date of visit December 03, 2019). 
chemical and physical properties of contaminants measured directly on their sources to determine a contribution made by a source into concentrations at monitoring posts for control over ground air (receptors);

- together with PFM, «HYSPLIT» (Hybrid Single Particle Lagrange Integrated Trajectory) software package is applied; this package allows modeling dispersion of contaminants taking into account meteorological data such as profiles of wind speeds and directions as well as temperatures at various heights;

- Modeling dispersion and turbulent diffusion of contaminants using Euler, lagrange, and Gauss models.

B.Kh. Sandjapov $\left[{ }^{2} 0\right]$ describes experience related to applying software packages for dispersion modeling WRF and CALPUFF that can be found on SCRAM web-site in Volgograd.

Difference solutions to turbulent diffusion equation reduced to a sequence of analytic expressions obtained via approximation and linearization of solutions to equations within Gauss model for dispersion are also applied in the methodology called «Techniques for calculating dispersion of adverse substances (contaminants) emitted into the atmosphere» ${ }^{6}$ fixed by the RF Ministry for Natural Resources and Environmental Protection No. 237 issued on June 06, 2017.

We think that when the above-mentioned tasks are fulfilled, it will allow obtaining data that are sufficient for identifying sources of elevated ambient air contamination in order to work out relevant management activities aimed at ambient air quality in cities meeting all the sanitary standards.

These management activities can be both operative measures, for example, a decrease in emission capacities of specific air contamina- tion sources or imposing limits on motor transport traffic, and strategic ones, for example, instructions issued for economic entities to develop environmental protection measures or construction of new motorways to redirect traffic flows.

To perform operative and strategic management of ambient air quality based on data obtained via monitoring and modeling, probably certain changes into ecological legislations are required; however, only time can tell whether they are necessary and what exactly should be changed in ecological laws and legislative acts.

Conclusion. To achieve relevant functioning of a system for managing ambient air quality in large industrial cities, it is necessary to perform the following steps: to equip emission sources located at objects belonging to the $1^{\text {st }}$ hazard category with devices for uninterrupted on-line automated control over contaminants emissions; to develop a system of stationary monitoring posts as regards a wide range of contaminants including substances with a foul smell supplemented with a system for temperature-wind atmospheric sounding in the lower troposphere; the given systems should use conventional techniques for modeling contaminants dispersion tested in world practice and receptor data analysis taking into account air movement trajectories in a monitoring zone. Should all the steps be fulfilled, it will allow making ambient air quality conform to sanitary standards for the sake of people who live in large industrial cities.

Funding. The research was not granted any sponsor support.

Conflict of interests. The authors state there is no any conflict of interests.

\section{References}

1. Zaitseva N.V., May I.V., Kleyn S.V., Goryaev D.V. Methodical approaches to selecting observation points and programs for observation over ambient air quality within social and hygienic monitoring and «Pure Air» Federal project. Health Risk Analysis, 2019, no. 3, pp. 4-17 (in Russian). DOI: 10.21668/health.risk/2019.3.01.eng

2. Kiselev A.V., Grigor'eva Ya.V. The use of results of the calculation of atmospheric pollution for the social hygienic monitoring. Gigiena i sanitariya, 2017, vol. 96, no. 4, pp. 306-309 (in Russian).

3. Vinokurova M.V., Vinokurov M.V., Gurvich V.B., Kuzmin S.V., Malykh O.L. Assessment of ambient air quality in the localities by the calculation method in the sociohygienic monitoring. Gigiena $i$ sanitariya, 2004, no. 5, pp. 25-26 (in Russian).

4. Klepikov O.V., Mamchik N.P., Kolnet I.V., Kurolap S.A., Khorpyakova T.V. Application of geoinformation technologies in regional systems of environmental monitoring and population health monitoring. Vestnik Udmurtskogo universiteta. Seriya Biologiya. Nauki o zemle, 2018, vol. 28, no. 3, pp. 249-256 (in Russian). 
5. Kostyleva N.V., Gileva T.E., Oputina I.P. Summary calculations of pollution of atmospheric air. Antropogennaya transformatsiya prirodnoi sredy, 2017, no. 3, pp. 106-107 (in Russian).

6. Igonin E.I., Shlychkov A.P., Shagidullin A.R., Shagidullin R.R. Optimization of the regional atmospheric air monitoring system on the example of Nizhnekamsk. Rossiiskii zhurnal prikladnoi ekologii, 2016, vol. 7, no. 3, pp. 33-39 (in Russian).

7. Shklyaev V.A., Kostareva T.V. Characteristics of the temperature in versions and the irrelationship with atmospheric air pollution in Perm. Geograficheskii vestnik, 2019, vol. 48, no. 1, pp. 84-92 (in Russian).

8. Gosudarstvennaya set' nablyudenii Permskogo kraya [The State monitoring system in Perm region]. Sait Permskogo tsentra po gidrometeorologii i monitoringu okruzhayushchei sredy. Available at: http:// meteo.perm.ru/gosudarstvennaya-set-nablyudenij-permskogo-kraya (05.12.2019) (in Russian).

9. Ayusheeva S.N., Botoeva N.B., Mikheeva A.S. Analysis of the impact of economic activity on atmospheric air quality in Ulan-Ude. IOP Conference Series: Earth and Environmental Science, 2019, vol. 320, no. 1,8 p. DOI: $10.1088 / 1755-1315 / 320 / 1 / 012009$

10. WHO releases country estimates on air pollution exposure and health impact. World Health Organization, 2016. Available at: https://www.who.int/news-room/detail/27-09-2016-who-releases-countryestimates-on-air-pollution-exposure-and-health-impact (05.12.2019).

11. Chernyaeva V.A., Wang D.H. Regional Environmental Features and Health Indicators Dynamics. Pollution of the Earth's Atmosphere and International Air Quality Standards. IOP Conference Series: Earth and Environmental Science, 2019, vol. 267, 6 p. DOI: 10.1088/1755-1315/267/6/062012

12. Nguyen N.P., Marshall J.D. Impact, efficiency, inequality, and injustice of urban air pollution: variability by emission location. Environmental Research Letters, 2018, vol. 13, no. 2 , 9 p. DOI: 10.1088/1748-9326/aa9cb5

13. Butt E.W., Turnock S.T., Rigby R., Reddington C.L., Yoshioka M., Johnson J.S., Regayre L.A., Pringle K.J. [et al.]. Global and regional trends in particulate air pollution and attributable health burden over the past 50 years. Environmental Research Letters, 2017, vol. 12, no. 10. DOI: 10.1088/1748-9326/aa87be

14. Nikiforova V.A., Vidishcheva D.D., Podoinitsyna N.A., Gleba V.S. Avtotransport i ego vliyanie na okruzhayushchuyu sredu [Motor transport and its effects on the environment]. Trudy Bratskogo gosudarstvennogo universiteta. Seriya: Estestvennye i inzhenernye nauki, 2017, vol. 1, pp. 192-194 (in Russian).

15. Golikov A.A., Abrosimova E.M. Prospects of development of monitoring complexes of mobile vehicles. Okhrana, bezopasnost', svyaz', 2019, vol. 1, no. 4 (4), pp. 37-40 (in Russian).

16. Lenskaya O.Yu., Abdullaev S.M., Prikazchikov A.I., Sobolev D.N. Modeling study of amospheric boundary layer characteristics in industrial city by the example of Chelyabinsk. Vestnik Yuzhno-Ural'skogo gosudarstvennogo universiteta. Seriya: Vychislitel'naya matematika i informatika, 2013, vol. 2, no. 2, pp. 65-82 (in Russian).

17. Doronin A.P., Timoshchuk A.S., Shabalin P.V. Rezul'taty issledovaniya meteorologicheskikh uslovii formirovaniya vysokikh urovnei zagryazneniya atmosfernogo vozdukha v Sankt-Peterburge po dannym za 2017 god [Results of the study on meteorological conditions that cause occurrence of substantial ambient air contamination in Saint Petersburg based on data collected in 2017]. Trudy Voenno-kosmicheskoi akademii im. A.F. Mozhaiskogo, 2018, no. 662, pp. 129-134 (in Russian).

18. Krasnenko N.P. Metody i sredstva distantsionnogo monitoringa i prognozirovaniya sostoyaniya nizhnei troposfery [Methods and tools for distant monitoring and predicting the situation in the lower troposphere]. Sovremennye problemy distantsionnogo zondirovaniya, radiolokatsii, rasprostraneniya i difraktsii voln: materialy vserossiiskoi otkrytoi nauchnoi konferentsii «Vserossiiskie otkrytye Armandovskie chteniya». Murom, 2019, pp. 20-29 (in Russian).

19. Support Center for Regulatory Atmospheric Modeling (SCRAM). EPA. Available at: https://www. epa.gov/scram (05.12.2019).

20. Sanzhapov B.Kh., Sinitsyn A.A., Rashevskii N.M. Usage of complex of open-source software WRF and CALPUFF for dispersion modeling of atmospheric pollutants in Volgograd. Izvestiya Volgogradskogo gosudarstvennogo tekhnicheskogo universiteta, 2017, vol. 196, no. 1, pp. 46-49 (in Russian).

Zhizhin N.N., D'yakov M.S., Khodyashev M.B. Analysis of tools aimed at managung ambient air qyality in Perm city. Health Risk Analysis, 2019, no. 4, pp. 50-59. DOI: 10.21668/health.risk/2019.4.05.eng

Received: 02.11.2019

Accepted: 19.12.2019

Published: 30.12.2019 